\title{
Statement of Work for Services Provided by the Waste Sampling and Characterization Facility for the Effluent and Environmental Monitoring Program Calendar Year 1999
}

Prepared for the U.S. Department of Energy Assistant Secretary for Environmental Management

FLUOR DANIEL HANFORD, INC. Richland, Washington

RECORD COPY 


\section{Statement of Work for Services} Provided by the Waste Sampling and Characterization Facility for the Effluent and Environmental Monitoring Program

\section{Calendar Year 1999}

Date Published

May 1999

Prepared for the U.S. Department of Energy Assistant Secretary for Environmental Management

FLUOR DANIEL HANFORD, INC.

Richland, Washington 


\section{RELEASE AUTHORIZATION}

Document

Number:

Document

Title:
HNF-EP-0835-3

Statement of Work for Services Provided by the Waste Sampling and Characterization Facility for the Effluent and Environmental Monitoring Program, Calendar Year 1999

\section{This document, reviewed in accordance with DOE Order 241.1, "Scientific and Technical Information Management," and DOE G 241.1-1, "Guide to the Management of Scientific and Technical Information," does not contain classified or sensitive unclassified information and is:}

\section{APPROVED FOR PUBLIC RELEASE}

\begin{tabular}{|c|c|}
\hline$\rho_{1}$ & $6 / 3 / 99$ \\
\hline C. WiTlingtam & Date \\
\hline $\begin{array}{l}\text { Lockheed Mart in Services, Inc. } \\
\text { Document Control/Information Release }\end{array}$ & \\
\hline
\end{tabular}

Reviewed for Applied Technology, Business Sensitive, Classified, Copyrighted, Export Controlled, Patent, Personal/Private, Proprietary, Protected CRADA, Trademark, Unclassified Controlled Nuclear Information.

Tradenark Disclaimer. Reference herein to any specific commercial product, process, or service by trade name, trademark, manufacturer, or otherwise, does not necessarily constitute or imply its endorsement, recommendation, or favoring by the United States Goverrment or any agency thereof or its contractors or subcontractors. The views and opinions of authors expressed herein do not necessarity state or reflect those of the United States Government or any agency thereof. This report has been reproduced from the best available copy.

Printed in the United States of America.

Available to the U.S. Department of Energy and its contractors from the U.S. Department of Energy office of Scientific and Technical Information, P.0. Box 62, Oak Ridge, TN 37831; Telephone: 423/576-8401. 
Document Title:

Approved by:

Approved by: $\frac{\text { ENu. Coreager, Manager }}{\text { WMH Air \& Water Services }}$

Approved by:
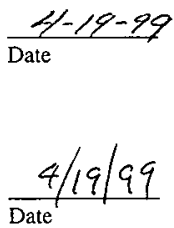

$$
5 / 21 / 99
$$

Date

WMNW Environmental Monitoring \& Investigations

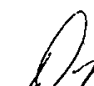

Approved by:

S. L. Fitzgerald, Rad ochemistry Team Leader

Andytienl Prodaction

WMH Waste Sampling and Characterization Facility

Approved by:

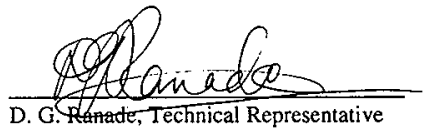

D. G. Technical Representative FDH Environmental Integration $\frac{4 \sqrt{20 / 99}}{\text { Date }}$ 
HNF-EP-0835-5

This page intentionally left blank. 


\section{CONTENTS}

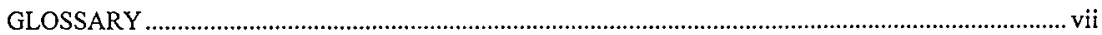

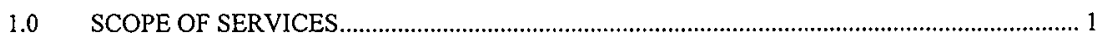

2.0 REGULATORY REPORTING REQUIREMENTS .........................................................

2.1 RADIONUCLIDE AIR EMISSIONS REPORT FOR THE CLEAN AIR ACT ......................... 1

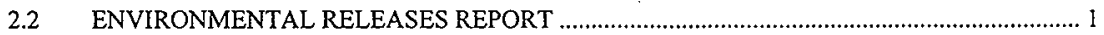

2.3 HANFORD SITE ENVIRONMENTAL REPORT ….......................................................... 2

2.4 EFFLUENT INFORMATION SYSTEM-ONSITE DISCHARGE INFORMATION

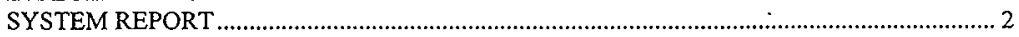

2.5 HANFORD SITE NEAR-FACILITY ENVIRONMENTAL MONITORING

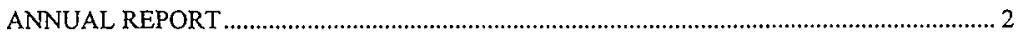

3.0 WASTE SAMPLING AND CHARACTERIZATION FACILITY SERVICES AND DATA

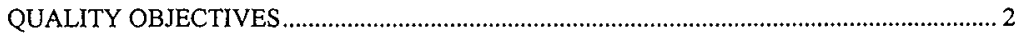

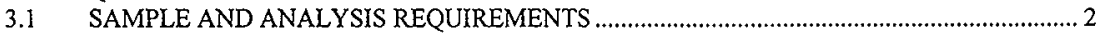

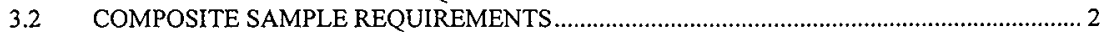

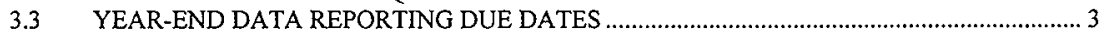

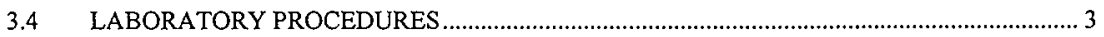

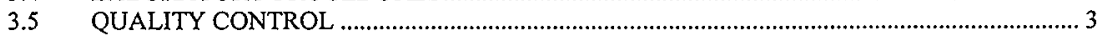

3.5.1 Quality Control Tests for Water, Vegetation, and Soil Sample Analyses..................................... 4

3.5.2 Quality Control Tests for Air Sample Analyses ........................................................................ 4

3.6 RETENTION OF AND ACCESS TO RAW DATA AND RESULTS …...............................5

3.7 ANALYTICAL ERROR AND MINIMUM DETECTABLE CONCENTRATION...................... 5

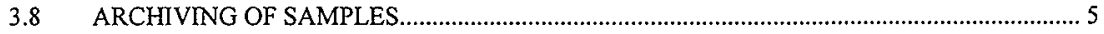

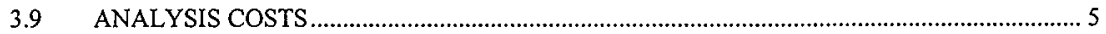

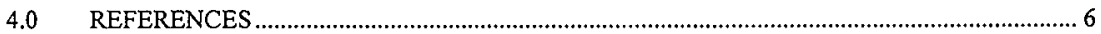

\section{ATTACHMENT}

ANALYTICAL REQUIREMENTS FOR ENVIRONMENTAL COMPLIANCE PROGRAM SAMPLING DURING CALENDAR YEAR 1999 ATT-1

\section{TABLES}

Table 1. Stack and Ambient Air Sample Analysis Criteria for Waste Sampling and Characterization Facility. 7

Table 2. Liquid Effluent Sample Analysis Criteria for Waste Sampling and Characterization Facility. .... 8

Table 3. Vegetation and Soil Samples, Sample Analysis Criteria for Waste Sampling and Characterization Facility. 9

Table 4. Additional Services Factored into Waste Sampling and Characterization Facility Sample Analysis Prices for Effluent and Environmental Monitoring Program. 
HNF-EP-0835-5

This page intentionally left blank. 


\section{GLOSSARY}

\section{ACRONYMS}

$\begin{array}{ll}\text { ABCASH } & \text { automated bar coding of air samples at Hanford } \\ \text { ARC } & \text { archive only } \\ \text { AWS } & \text { WMH Air \& Water Services Organization } \\ \text { CACN } & \text { cost account charge number } \\ \text { CAM } & \text { continuous air monitor } \\ \text { CSB } & \text { Canister Storage Building } \\ \text { DOE } & \text { U.S. Department of Energy } \\ \text { DOE-RL } & \text { U.S. Department of Energy, Richland Operations Office } \\ \text { ECP } & \text { Environmental Compliance Program } \\ \text { EDP } & \text { electronic data processing } \\ \text { EEM } & \text { effluent and environmental monitoring } \\ \text { EIS-ODIS } & \text { effluent information system-onsite discharge information system } \\ \text { EMI } & \text { WMNW Environmental Monitoring \& Investigations Organization } \\ \text { EML } & \text { Environmental Measurements Laboratory } \\ \text { EPA } & \text { U.S. Environmental Protection Agency } \\ \text { ERC } & \text { Environmental Restoration Contract } \\ \text { ERDF } & \text { Environmental Restoration Disposal Facility } \\ \text { ETF } & \text { Effluent Treatment Facility } \\ \text { FFTF } & \text { Fast Flux Test Facility } \\ \text { GEA } & \text { gamma energy analysis } \\ \text { LCS } & \text { Laboratory Control Standards } \\ \text { MDA } & \text { minimum detectable activity } \\ \text { MDC } & \text { minimum detectable concentration } \\ \text { MDL } & \text { minimum detection limit } \\ \text { N/A } & \text { not applicable } \\ \text { NFM } & \text { near-facility monitoring } \\ \text { PCB } & \text { polychlorinated biphenyls } \\ \text { PHMC } & \text { Project Hanford Management Contract } \\ \text { PNNL } & \text { Pacific Northwest National Laboratory } \\ \text { PFP } & \text { Plutonium Finishing Plant } \\ \text { PUREX } & \text { Plutonium-Uranium Extraction (Facility) } \\ \text { QC } & \text { quality control } \\ \text { TT } & \text { turnaround time } \\ \text { TBD } & \text { to be determined } \\ \text { TEDF } & \text { Treated Effluent Disposal Facility } \\ \text { TRUSAF } & \text { Transuranic Waste Storage and Assay Facility } \\ \text { TWRS } & \text { Tank Waste Remediation System } \\ \text { WAC } & \text { Washington Administrative Code } \\ \text { WESF } & \text { Waste Encapsulation and Storage Facility } \\ \text { WMH } & \text { Waste Management Federal Services of Hanford, Inc. } \\ \text { WMNW } & \text { Waste Management Federal Services Northwest, Inc., Northwest Operations } \\ \text { WRAP } & \text { Waste Receiving and Processing } \\ \text { WSCF } & \text { Waste Sampling and Characterization Facility } \\ & \\ & \end{array}$


HNF-EP-0835-5

\section{GLOSSARY (cont)}

$\begin{array}{ll}\mathrm{ft}^{3} & \text { cubic foot } \\ \mathrm{g} & \text { grams } \\ \mathrm{g} / \mathrm{mL} & \text { grams per milliliter } \\ \mathrm{L} & \text { liter } \\ \mathrm{ml} & \text { milliliter } \\ \mathrm{pCi} / \mathrm{g} & \text { picocurie per gram } \\ \mathrm{pH} & \text { potential of hydrogen } \\ \mathrm{ppm} & \text { parts per million } \\ (\$) & \text { dollars } \\ \mu \mathrm{Ci} & \text { microcurie } \\ \mu \mathrm{Ci} / \mathrm{mL} & \text { microcurie per milliliter. }\end{array}$

\section{TERMS}

Accuracy. The degree of agreement of a measurement with a true or known value.

Completeness. A measure of the amount of valid and usable data obtained from a measurement system compared to the amount that was expected to be obtained under correct normal conditions.

Precision. A measure of mutual agreement among individual measurements of the same property under similar conditions. Precision is best expressed in terms of standard deviation.

Turnaround time. Elapsed time, in days, starting from the receipt of all samples to be analyzed and all relevant sampling data, and ending when the results, in units of concentration, are received electronically. 
HNF-EP-0835-5

\section{STATEMENT OF WORK FOR SERVICES PROVIDED BY THE WASTE SAMPLING AND CHARACTERIZATION FACILITY FOR THE EFFLUENT AND ENVIRONMENTAL MONITORING PROGRAM, CALENDAR YEAR 1999}

\subsection{SCOPE OF SERVICES}

This document defines the services that the Waste Sampling and Characterization Facility (WSCF) shall provide the Environmental Compliance Program (ECP) throughout the calendar year for effluent and environmental monitoring (EEM) analysis. One of the purposes of EEM is to monitor liquid and gaseous effluents and the environment immediately around facilities that might contain radioactive and hazardous materials. Monitoring data are collected, evaluated, and reported to determine the degree of compliance with applicable federal and state regulations and permits.

Samples to be submitted for analysis in calendar year (CY) 1999 are identified in the Attachment. Analysis of effluent (liquid and air discharges) and environmental (air, liquid, animal, and vegetative) samples is required using standard laboratory procedures, in accordance with regulatory and control requirements cited in NESHAP Quality Assurance Project Plan for Radioactive Air Emissions Data (HNF-EP-0528-3), Near-Facility Environmental Monitoring Quality Assurance Project Plan (HNF-EP-0538-3), and Hanford Analytical Services Quality Assurance Requirements Documents (DOE/RL-96-68). Should changes to this Statement of Work be necessary, WSCF or the Waste Management Federal Services, Inc. (WMH) Air \& Water Services (AWS) organization could amend the document at any time with a jointly approved internal memo.

\subsection{REGULATORY REPORTING REQUIREMENTS}

It is essential for the WSCF to meet the due dates specified. The analytical data required by these due dates are necessary to maintain compliance with environmental release reporting commitments mandated by regulatory agencies and the U.S. Department of Energy (DOE). Variances to technical criteria or due dates in this document must be documented by WSCF and approved or acknowledged by AWS.

\subsection{RADIONUCLIDE AIR EMISSIONS REPORT FOR THE CLEAN AIR ACT}

This report documents radionuclide air emissions from the Hanford Site and the resulting effective dose equivalent to any member of the public from those emissions. This report complies with the reporting requirements of the Code of Federal Regulations (CFR), Title 40, "Protection of the Environment," Part 61, "National Emissions Standards for Hazardous Air Pollutants," Subpart H, "National Emission Standards for Emissions of Radionuclides Other Than Radon From Department of Energy Facilities" (40 CFR 61 Subpart H) and Chapter 246-247 of the Washington Administrative Code (WAC).

\subsection{ENVIRONMENTAL RELEASES REPORT}

The report fulfills the effluent discharge reporting requirements of DOE Order 5400.1 and summarizes the compliance status of effluent releases from facilities under the Project Hanford Management Contract (PHMC) and the Environmental Restoration Contractor (ERC). 


\subsection{HANFORD SITE ENVIRONMENTAL REPORT}

Pacific Northwest National Laboratory (PNNL) annually compiles and publishes this report for DOE, in compliance with DOE Order 5400.1. AWS and Waste Management Federal Services, Inc., Northwest Operations (WMNW) Environmental Monitoring \& Investigations Organization (EMI) provide the effluent and near-facility monitoring (NFM) sections of this report.

\subsection{EFFLUENT INFORMATION SYSTEM-ONSITE DISCHARGE INFORMATION SYSTEM REPORT}

Each year AWS compiles and transmits this report electronically, for all Hanford Site contractors, to the Idaho National Environmental and Engineering Laboratory in Idaho Falls, Idaho, for inclusion in the effluent information system/onsite discharge information system (EIS/ODIS) database, in compliance with DOE Order 5484.1.

\subsection{HANFORD SITE NEAR-FACILITY ENVIRONMENTAL MONITORING ANNUAL REPORT}

EMI publishes this annual report for the ECP. The report provides a yearly summary of sampling and analysis of soil, vegetation, ambient air, etc., near Hanford Site facilities. This monitoring is performed in accordance with 40 CFR 61, Subpart H; WAC 246-247; and DOE Orders 5400.1 and 5820.2A requirements.

\subsection{WASTE SAMPLING AND CHARACTERIZATION FACILITY SERVICES AND DATA QUALITY OBJECTIVES}

WSCF shall provide the following analytical services when analyzing EEM low-level effluent and environmental samples.

\subsection{SAMPLE AND ANALYSIS REQUIREMENTS}

All services necessary shall be provided to complete the analytical requirements listed in Tables 1 through 4. Analyses shall be performed in accordance with applicable requirements and procedures contained in the references listed in Section 1.0. Analytical results shall be expressed in the units shown in the tables for the respective minimum detectable levels (MDLs).

\subsection{COMPOSITE SAMPLE REQUIREMENTS}

Effluent air emission samples shall be combined quarterly or monthly into composite samples and the first three quarters shall be reported electronically to AWS by the following dates:

- First quarter air emission composite sample results

June 30, 1999

- Second quarter air emission composite sample results September 30, 1999

- Third quarter air emission composite sample results. December 31, 1999 
Ambient air samples shall be combined into composite samples biannually and reported electronically to EMI within 90 days of receiving all samples and data needed to create the composite sample. All results shall be in units of concentration unless otherwise specified.

\subsection{YEAR-END DATA REPORTING DUE DATES}

The due date for submission of year-end analysis results to AWS for all samples collected up through December 31 st is:

- Air emission data February 15, 2000

The due date for submission of year-end analysis results to EMI for all samples collected up through December 31 st is:

- Environmental data

(air, surface water, and pond vegetation and sediment) March 15, 2000

All results shall be transmitted electronically and shall be in units of concentration unless otherwise specified. The analysis results from any weekly, biweekly, or monthly air samples collected on or after January 1 st will be applied to that year.

\subsection{LABORATORY PROCEDURES}

WSCF shall use laboratory analytical procedures that are:

- In compliance with EPA Method 114, Section 4.0, "Quality Assurance Methods," 40 CFR Part 61, Appendix B (specifically, 4.4 and 4.5 ), and applicable requirements and procedures contained in the references listed in Section 1.0

- In compliance with Chapter 6.0 of the Environmental Regulatory Guide for Radiological Effluent Monitoring and Environmental Surveillance document (DOE-EH-0173T)

- In compliance with the requirements specified in the Hanford Analytical Services Quality Assurance Requirements Documents (DOE/RL-96-68)

- Appropriate to the sample medium, sample size, and the analysis requirements listed in Tables 1 through 4.

\subsection{QUALTYY CONTROL}

WSCF shall ensure the integrity and validity of analytical test results through implementation of an internal quality control program. Standard methods shall be used whenever possible and methods that are developed or adapted shall be tested and completely documented.

Calibration and quality controls methods shall be performed using methods consistent with DOE/RL-96-68. WSCF shall provide data biannually to AWS that demonstrate that the data quality objectives for accuracy, precision, and completeness have been met. Auditable quality control (QC) test 
results shall be provided within 2 weeks of requesting specific records, without any additional charges. Regulator requests for records will be provided as soon as possible.

WSCF shall participate in the U.S. DOE Environmental Measurements Laboratory (EML) intercomparison program, as required per DOE/EH-0173T. EML laboratory inter-comparison results shall be provided annually.

\subsubsection{Quality Control Tests for Water, Vegetation, and Soil Sample Analyses}

These QC tests shall be for accuracy, precision, and completeness. The results of all QC tests shall be documented. Analytical problems identified through analysis of QC samples shall be corrected promptly. WSCF shall produce a minimum of 90 percent usable and valid analytical data for all ECP-related samples received. WSCF shall provide data to AWS that demonstrate that the accuracy, precision, and completeness objectives have been met.

WSCF shall prepare and analyze laboratory control standards (LCSs), blank, and duplicate samples to verify the accuracy and precision of all radiochemical methods. The total number of all QC samples shall be no less than 10 percent of all ordered sample analyses. The LCSs shall be included with each batch of samples processed and have, insofar as possible, a matrix, volume, mass, and other relevant characteristics of the actual samples being analyzed. The LCSs shall have range of activity from 5 times to no greater than 20 times the MDL values in Tables 1 through 4.

Method accuracy requirements shall be met when 95 percent of the LCS results fall within \pm 25 percent. Precision requirements shall be met when duplicate results, for samples $\geq 5$ times the MDL values in Tables 1 through 4 or when the analytical uncertainty is $\leq 20$ percent, fall within \pm 30 percent relative percent difference.

\subsubsection{Quality Control Tests for Air Sample Analyses}

These QC tests shall be for accuracy, precision, and completeness. The results of all QC tests shall be documented. Analytical problems identified through analysis of QC samples shall be corrected promptly. WSCF shall produce a minimum of 90 percent usable analytical data for all EEM-related samples received. WSCF shall provide data biannually to AWS that demonstrates that the accuracy, precision, and completeness objectives have been met.

Accuracy requirements shall be met when 95 percent of the results from counting instrument performance check standards fall within \pm 25 percent. Precision of air sample data shall be evaluated by recounting a portion of the samples analyzed, as the creation of duplicate samples is not feasible for air samples. AWS will identify quarterly the samples to be used for precision analysis. A minimum of 10 percent of the samples analyzed, in which the sample results will be used for calculating effluent emissions, shall be recounted to determine precision, approximately 70 samples. Precision requirements shall be met when samples, with activities $\geq 5$ times the MDL values in Tables 1 through 4 or when the analytical uncertainty is $\leq 20$ percent, fall within \pm 30 percent relative percent difference.

The requirements of Section 3.5.1 apply to air sample analyses that involve radiochemical separations. The data quality objectives for air samples requiring radiochemical separations shall be met when the objectives as specified Section 3.5.1 are met. 
HNF-EP-0835-5

\subsection{RETENTION OF AND ACCESS TO RAW DATA AND RESULTS}

All raw data and analytical results shall be retained as quality assurance documents for a minimum of 5 years, as specified by 40 CFR 61 , Subpart $\mathrm{H}$.

As needed, AWS shall have access to all available EEM-related raw data and results. WSCF shail provide analysis printouts upon request (e.g., gamma energy analysis list of identified peaks).

\subsection{ANALYTICAL ERROR AND MINIMUM DETECTABLE CONCENTRATION}

WSCF shall provide the overall analytical error associated with each analytical result. Total analytical error shall be calculated at the 95 percent confidence interval.

WSCF shall ensure that the MDL of the sample does not exceed the values specified in Tables 1 through 4.

\subsection{ARCHIVING OF SAMPLES}

Ambient air monitoring samples shall be archived on the completion of the total alpha and beta analysis. Archived ambient air samples shall be combined into composite samples and analyzed biannually by WSCF. These samples shall be identified as samples with the Nxxx series electronic data processing (EDP) codes.

Effluent air samples with EDP codes listed in the Table A-2 of the Attachment shall be archived before performing any analyses. On receipt, WSCF shall sort effluent samples into samples to be analyzed and samples to be archived, regardless of any labeling on the samples. WSCF shall enter the sample collection data into automated bar coding of air samples at Hanford (ABCASH), when samples with EDP codes listed in Tables A1 and A2 have not been entered by the facility into ABCASH. After each quarter, AWS will provide specific analysis instructions to WSCF regarding the archived samples. All archived effluent air samples, from CY-1999, can be disposed after July 15, 2000. Following the preparation of composite samples, any residual liquid may be disposed of after 60 days.

Backup record and effluent continuous air monitor (CAM) air samples shall not be analyzed but shall be archived until July 15, 2000. These samples can be identified as the samples received in white envelopes stamped "Archive Only", with EDP codes that are not listed in the Attachment.

\subsection{ANALYSIS COSTS}

The sample analysis costs are provided in Tables 1 through 4. These costs contain additional fees associated with services specific to ECP. Table 5 contains additional services factored into unit prices. The analysis costs in Tables 1 through 4 are estimated and could fluctuate because of changes in prices and workscope. Adjustments made to sample analysis costs shall have the concurrence of AWS. Tables A-1 through A-5 include the cost account charge numbers (CACNs) to assist in charging analysis costs to the appropriate cost account.

Note: Base unit prices will increase by $10 \%$ effective June 1, 1999 through September 30, 2000. The increase is included in the unit prices quoted in Tables 1 through 4. 


\subsection{REFERENCES}

DOE Order 5400.1, General Environmental Protection Program.

DOE Order 5820.2A, Radioactive Waste Management.

DOE Order 5484.1, Environmental Protection, Safety and Health Protection Information Reporting Requirements.

DOE/EH-0173T, Environmental Regulatory Guide for Radiological Effluent Monitoring and Environmental Surveillance, 1991.

DOE/RL-96-68, Hanford Analytical Services Quality Assurance Requirements Documents, U.S. Department of Energy, Richland Operations Office, Richland, Washington, 1996.

HNF-EP-0528-3, NESHAP Quality Assurance Project Plan for Radioactive Air Emissions, September 1998, Fluor Daniel Hanford, Inc., Richland, Washington.

HNF-EP-0538-3, Near-Facility Environmental Monitoring Quality Assurance Project Plan, November 1997, Fluor Daniel Hanford, Inc., Richland, Washington.

WAC 246-247, Washington Administrative Code Chapter 246-247, "Radiation Protection - Air Emissions," as amended, Washington Department of Health, Olympia, Washington. 
Table 1. Stack and Ambient Air Sample Analysis Criteria for Waste Sampling and Characterization Facility.

\begin{tabular}{|c|c|c|c|c|c|}
\hline $\begin{array}{l}\text { Nominal } \\
\text { sample } \\
\text { volume } \\
\text { volume }\end{array}$ & 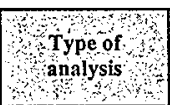 & $\begin{array}{r}\mathrm{MDC} \\
(\mu \mathrm{C} \mathrm{i} / \mathrm{m})\end{array}$ & $\begin{array}{l}\mathrm{MDA}^{\mathrm{b}} \\
(\mathrm{pCi}) \mathrm{O}\end{array}$ & $\begin{array}{c}\text { TT } \\
\text { (days) }\end{array}$ & $\begin{array}{l}\text { Unit price } \\
\text { (\$) }\end{array}$ \\
\hline \multirow{2}{*}{$\begin{array}{c}20,000 \mathrm{ft}^{3} \\
(5.66 \mathrm{E} 8 \mathrm{ml})\end{array}$} & Total $\alpha / \beta$ & $\begin{array}{l}2.0 \mathrm{E}-15(\alpha) \\
\text { and } \\
1.9 \mathrm{E}-14(\beta)\end{array}$ & $\begin{array}{l}1.1 \mathrm{E}-6(\alpha) \\
\text { and } \\
1.1 \mathrm{E}-5(\beta)\end{array}$ & 14 & 155 \\
\hline & Ag zeolite & $\begin{array}{c}3.4 \mathrm{E}-13 \\
\left({ }^{106} \mathrm{Ru}\right)\end{array}$ & $\begin{array}{l}1.9 \mathrm{E}-4 \\
\left({ }^{106} \mathrm{Ru}\right)\end{array}$ & 30 & 272 \\
\hline \multirow{6}{*}{$\begin{array}{c}262,000 \mathrm{ft}^{3} \\
(7.42 \mathrm{E} 9 \mathrm{ml})\end{array}$} & ${ }^{90} \mathrm{Sr}$ & $1.9 \mathrm{E}-14$ & $1.4 \mathrm{E}-4$ & 90 & 310 \\
\hline & $\mathrm{GEA}^{\mathrm{d}}$ & $\begin{array}{c}1.9 \mathrm{E}-14 \\
\left({ }^{137} \mathrm{Cs}\right)\end{array}$ & $\begin{array}{l}1.4 \mathrm{E}-4 \\
\left({ }^{437} \mathrm{Cs}\right)\end{array}$ & 90 & 194 \\
\hline & $\begin{array}{l}\text { Isotopic } U \\
\left({ }^{234} \mathrm{U},{ }^{235} \mathrm{U},\right. \\
\left.{ }^{238} \mathrm{U}\right)\end{array}$ & $7.1 \mathrm{E}-15$ & $5.3 \mathrm{E}-5$ & 90 & 388 \\
\hline & $\begin{array}{c}\text { Isotopic } \mathrm{Pu} \\
\left({ }^{238} \mathrm{Pu},{ }^{239 / 240} \mathrm{Pu}\right)\end{array}$ & $2.0 \mathrm{E}-15$ & $1.5 \mathrm{E}-5$ & 90 & 427 \\
\hline & ${ }^{241} \mathrm{Pu}$ & $1.0 \mathrm{E}-13$ & $7.4 \mathrm{E}-4$ & 90 & 465 \\
\hline & ${ }^{241} \mathrm{Am}$ & $1.9 \mathrm{E}-15$ & $1.4 \mathrm{E}-5$ & 90 & 388 \\
\hline $\begin{array}{c}262,000 \mathrm{ft}^{3} \\
(7.42 \mathrm{E} 9 \mathrm{ml})\end{array}$ & $\begin{array}{c}\text { Total } \alpha / \beta \\
\text { Composite } \\
\text { Analysis }\end{array}$ & $\begin{array}{c}2.0 \mathrm{E}-15(\alpha) \\
\text { and } \\
1.9 \mathrm{E}-14(\beta)\end{array}$ & $\begin{array}{c}1.5 \mathrm{E}-5(\alpha) \\
\text { and } \\
1.4 \mathrm{E}-4(\beta)\end{array}$ & 90 & 155 \\
\hline $\begin{array}{c}22 \mathrm{ft}^{3} \\
(6.23 \mathrm{E} 5 \mathrm{ml})\end{array}$ & Tritium & $1.5 \mathrm{E}-9$ & 9.3 E-04 & 90 & 155 \\
\hline
\end{tabular}

a MDCs obtained from 40 CFR 61, Appendix E Table II.

b MDAs shall be as low as reasonably attainable, but shall not exceed the values specified in the table. MDA values obtained from $40 \mathrm{CFR} 61$, Appendix $\mathrm{E}$ Table II and multiplied by the nominal sample volume. A minimum sample volume of $20,000 \mathrm{ft}^{3}$ is expected for all analyses, with the exception of tritium., which is $22 \mathrm{ft}^{3}$.

c These prices contain additional fees associated with services specific to the ECP. Table 5 contains additional services factored into unit prices. Price increase effective June 1, 1999.

d All positive gamma energy analysis results shall be reported, with the exception of the short-lived ${ }^{222} \mathrm{Rn}$ and ${ }^{220} \mathrm{Rn}$ progeny.

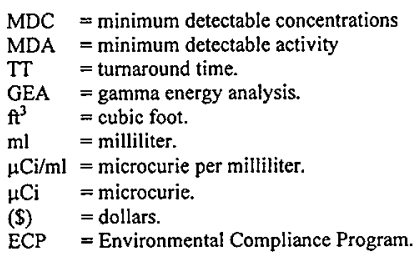


Table 2. Liquid Effluent Sample Analysis Criteria for Waste Sampling and Characterization Facilitya.

\begin{tabular}{|c|c|c|c|c|}
\hline $\begin{array}{c}\text { कीp } \\
\text { Sample size } \\
\text { nats }\end{array}$ & 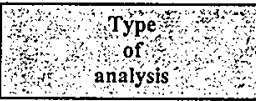 & $\begin{array}{r}\mathrm{MDCb} \\
(\mu \mathrm{C} / / \mathbf{m L})^{\mathrm{c}}\end{array}$ & $\begin{array}{r}\text { TT } \\
\text { (days) }\end{array}$ & $\begin{array}{r}\text { Unitprice } \\
\text { (\$) }\end{array}$ \\
\hline \multicolumn{5}{|c|}{ Radiological Analyses } \\
\hline \multirow{7}{*}{$1.0 \mathrm{~L}$} & Total $\alpha / \beta$ & $\begin{array}{c}1.2 \mathrm{E}-09(\alpha) \\
\text { and } \\
4.0 \mathrm{E}-08(\beta)\end{array}$ & 45 & 155 \\
\hline & ${ }^{3} \mathrm{H}$ & $8.0 \mathrm{E}-05$ & 45 & 155 \\
\hline & ${ }^{90} \mathrm{Sr}$ & $4.0 \mathrm{E}-08$ & 45 & 264 \\
\hline & $\mathrm{GEA}^{\mathrm{e}}$ & $\begin{array}{c}1.2 \mathrm{E}-07 \\
\left({ }^{137} \mathrm{Cs}\right)\end{array}$ & 45 & 194 \\
\hline & $\begin{array}{c}\text { Isotopic U } \\
\left({ }^{234} \mathrm{U},{ }^{231} \mathrm{U},{ }^{238} \mathrm{U}\right)\end{array}$ & $2.0 \mathrm{E}-08$ & 45 & 310 \\
\hline & $\begin{array}{c}\text { Isotopic Pu } \\
\left({ }^{238} \mathrm{Pu},{ }^{239 / 240} \mathrm{Pu}\right)\end{array}$ & $1.2 \mathrm{E}-09$ & 45 & 326 \\
\hline & ${ }^{241} \mathrm{Am}$ & $1.2 \mathrm{E}-09$ & 45 & 310 \\
\hline \multicolumn{5}{|c|}{ Nonradiological Analyses } \\
\hline \multirow{2}{*}{$1.0 \mathrm{~L}$} & $\mathrm{pH}$ & NA & 60 & 28 \\
\hline & $\mathrm{NO}_{3}$ & $1.0 \mathrm{E}-06 \mathrm{~g} / \mathrm{mL}$ & 60 & 233 \\
\hline
\end{tabular}

a Liquid effluent samples shall be analyzed unfiltered, whereas groundwater samples shall be filtered and only the filtrate analyzed.

b MDCs shall be as low as reasonably attainable, but shall not exceed the values specified in the table. MDC values obtained from 4 percent of the derived concentration guidelines.

c Unless other units of measure are indicated.

d These prices contain additional fees associated with services specific to the ECP. Table 5 contains a detailed list of the additional services factored into unit prices. Price increase effective June 1, 1999.

e All positive gamma energy analysis results shall be reported, with the exception of the short-lived ${ }^{222} \mathrm{Rn}$ and ${ }^{220} \mathrm{Rn}$ progeny.

$\mathrm{GEA}=$ gamma energy analysis.

MDC = minimum detectable concentration

TT = turnaround time.

$\mathrm{L} \quad=$ liter.

$\mu \mathrm{Ci} / \mathrm{mL}=$ microcurie per milliliter.

(\$) = dollars

$\mathrm{g} / \mathrm{mL}=$ grams per milliliter.

ECP = Environmental Compliance Program. 
Table 3. Vegetation and Soil Samples, Sample Analysis Criteria for Waste Sampling and Characterization Facility.

\begin{tabular}{|c|c|c|c|c|}
\hline 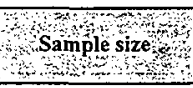 & $\begin{array}{c}\text { Type of } \\
\text { annalysis }\end{array}$ & MDC & $\begin{array}{l}\mathrm{TT} \\
\text { (days) }\end{array}$ & Unit price \\
\hline \multicolumn{5}{|c|}{ Radiological Analyses } \\
\hline $500 \mathrm{~g}$ (dry wt) & ${ }^{90} \mathrm{Sr}$ & $1.0 \mathrm{pCi} / \mathrm{g}$ & 45 & 350 \\
\hline $500 \mathrm{~g}$ (dry wt) & $\mathrm{GEA}^{b}$ & $\begin{array}{c}0.20 \mathrm{pCi} / \mathrm{g} \\
\left({ }^{137} \mathrm{Cs}\right)\end{array}$ & 45 & 226 \\
\hline $500 \mathrm{~g}$ (dry wt) & $\left(\begin{array}{c}\text { Isotopic } U \\
\left({ }^{234} \mathrm{U},{ }^{233} \mathrm{U},{ }^{238} \mathrm{U}\right)\end{array}\right.$ & $0.040 \mathrm{pCi} / \mathrm{g}$ & 45 & 427 \\
\hline $500 \mathrm{~g}$ (dry wt) & $\begin{array}{c}\text { Isotopic } \mathrm{Pu} \\
\left({ }^{238} \mathrm{Pu},{ }^{239 / 240} \mathrm{Pu}\right)\end{array}$ & $1.0 \mathrm{pCi} / \mathrm{g}$ & 45 & 427 \\
\hline $500 \mathrm{~g}$ (dry wt) & ${ }^{241} \mathrm{Pu}$ & $1.0 \mathrm{pCi} / \mathrm{g}$ & 45 & 465 \\
\hline $500 \mathrm{~g}$ (dry wt) & ${ }^{241} \mathrm{Am}$ & $1.0 \mathrm{pCi} / \mathrm{g}$ & 45 & $388^{d}$ \\
\hline $500 \mathrm{~g}$ (dry wt) & ${ }^{244} \mathrm{Cm}$ & $1.0 \mathrm{pCi} / \mathrm{g}$ & 45 & $388^{d}$ \\
\hline \multicolumn{5}{|c|}{ Nonradiological Analyses } \\
\hline $\mathrm{N} / \mathrm{A}$ & $\mathrm{pH}$ & $\mathrm{N} / \mathrm{A}$ & 45 & 40 \\
\hline $200 \mathrm{~g}$ & Anions & $1.0 \mathrm{ppm}$ & 45 & 310 \\
\hline $200 \mathrm{~g}$ & $\begin{array}{l}\text { Metals } \\
\text { EPA Method } \\
200.8^{\mathrm{c}}\end{array}$ & $1.0 \mathrm{ppm}$ & 45 & 273 \\
\hline $200 \mathrm{~g}$ & Cyanide & $1.0 \mathrm{ppm}$ & 45 & 186 \\
\hline $200 \mathrm{~g}$ & PCB & & 45 & 162 \\
\hline
\end{tabular}

a 30 day tumaround times are available for a higher price. Prices for 30 day turnaround times are approximately 1.5 the 45 -day turnaround price for most sample analyses.

b All positive gamma energy analysis results shall be reported, with the exception of the short-lived ${ }^{222} \mathrm{Rn}$ and ${ }^{220}$ Rn progeny.

c The minimum list of metals for EPA Method 200.7 shall include: $\mathrm{Ag}, \mathrm{Al}, \mathrm{As}, \mathrm{B}, \mathrm{Ba}, \mathrm{Be}, \mathrm{Ca}, \mathrm{Cd}, \mathrm{Co}, \mathrm{Cr}, \mathrm{Cu}$, $\mathrm{Fe}, \mathrm{K}, \mathrm{Li}, \mathrm{Mg}, \mathrm{Mn}, \mathrm{Na}, \mathrm{Ni}, \mathrm{P}, \mathrm{Pb}, \mathrm{Sc}, \mathrm{Se}, \mathrm{Si}, \mathrm{Sb}, \mathrm{Sr}, \mathrm{Th}, \mathrm{Ti}, \mathrm{U}, \mathrm{V}, \mathrm{Y}, \mathrm{Zn}, \mathrm{Zr}$.

d When ${ }^{241} \mathrm{Am}$ and ${ }^{244} \mathrm{Cm}$ are requested together, the combined price is $\$ 388$.

e WSCF unit prices increase $10 \%$ effective June $1,1999$.

$\mathrm{MDC}=$ minimum detectable concentration

TT = turnaround time

N/A = not applicable.

g = grams.

$\mathrm{PCB}=$ polychlorinated biphenyls.

$\mathrm{pCi} / \mathrm{g}=$ picocuries per gram.

ppm $=$ parts per million .

$\mathrm{pH}=$ potential of hydrogen.

$\mathrm{EPA}=$ U.S. Environmental Protection Agency. 
Table 4. Additional Services Factored into Waste Sampling and Characterization

Facility Sample Analysis Prices for Effluent and Environmental Monitoring.

\begin{tabular}{|c|c|}
\hline $\begin{array}{l}\text { Sample } \\
\text { Sategory }\end{array}$ & servicesprovided Additional \\
\hline \multirow{10}{*}{$\begin{array}{l}\text { Air } \\
\text { samples }\end{array}$} & $\begin{array}{l}\text { Entering sample collection data into ABCASH for facilities not equipped with } \\
\text { barcoding equipment. }\end{array}$ \\
\hline & Downloading all air sample results into ABCASH. \\
\hline & Disposal of samples and waste from chemical processing. \\
\hline & $\begin{array}{l}\text { Archiving near-field monitoring samples and effluent samples from major } \\
\text { emission units that receive composite analyses. }\end{array}$ \\
\hline & Archiving samples from minor emission units that receive quarterly analysis. \\
\hline & $\begin{array}{l}\text { Archiving backup effluent samples and effluent samples from minor emission } \\
\text { units that do not get analyzed. }\end{array}$ \\
\hline & Notifying AWS about zero ABCASH results. \\
\hline & $\begin{array}{l}\text { Sorting effluent samples into two groups: (1) samples to be analyzed and } \\
\text { (2) samples to be archived. }\end{array}$ \\
\hline & Assembly and preparation of samples for composite analysis. \\
\hline & $\begin{array}{l}\text { Preparation and analysis of QC samples (e.g., control standards, blanks, } \\
\text { duplicates, matrix spikes, etc.). }\end{array}$ \\
\hline \multirow{5}{*}{$\begin{array}{l}\text { Liquid } \\
\text { samples }\end{array}$} & Archiving samples until composite analysis is performed. \\
\hline & Archiving unused samples until EEM reports are issued. \\
\hline & $\begin{array}{l}\text { Assembly and preparation of samples for composite analysis. Includes verifying } \\
\text { receipt of all samples for composite, calculating effluent stream volumes, and } \\
\text { determining aliquot sizes for composite. }\end{array}$ \\
\hline & Disposal of samples and waste from chemical processing. \\
\hline & $\begin{array}{l}\text { Preparation and analysis of QC samples (e.g., control standards, blanks, } \\
\text { duplicates, matrix spikes, etc.) }\end{array}$ \\
\hline \multirow{4}{*}{ Miscellaneous } & Supporting audits of the EEM activities. \\
\hline & Participate in the prescribed laboratory intercomparison programs. \\
\hline & Provide laboratory intercomparison results to AWS. \\
\hline & Perform rush and emergency sample analyses. \\
\hline
\end{tabular}

ABCASH $=$ automated bar coding of air samples at Hanford.

QC = quality control.

AWS = Waste Management Federal Services of Hanford, Inc., Air \& Water Services Organization. 
HNF-EP-0835-5

ATTACHMENT

\author{
ANALYTICAL REQUIREMENTS \\ FOR \\ ENVIRONMENTAL COMPLIANCE PROGRAM SAMPLING \\ DURING CALENDAR YEAR 1999
}


HNF-EP-0835-5

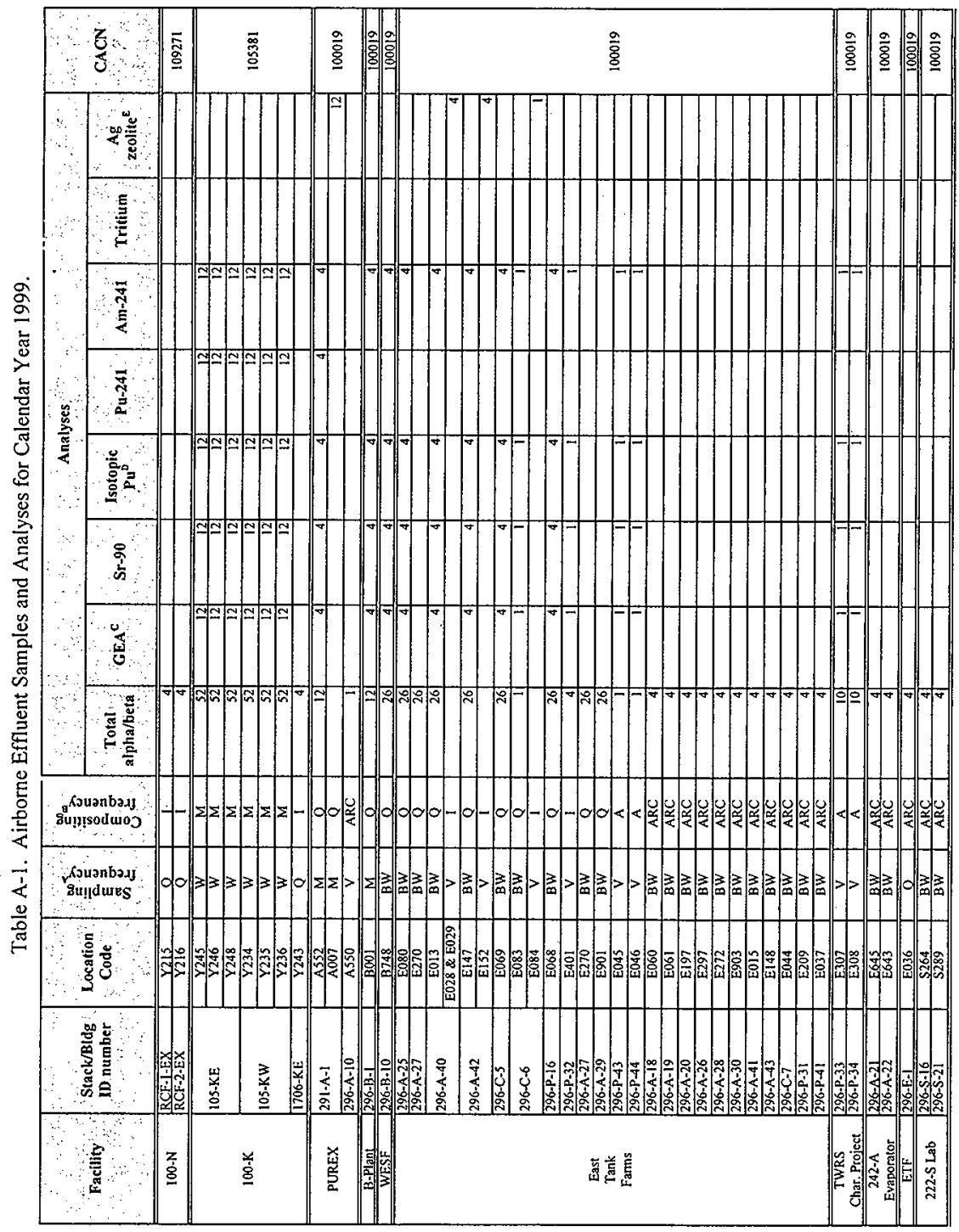


HNF-EP-0835-5

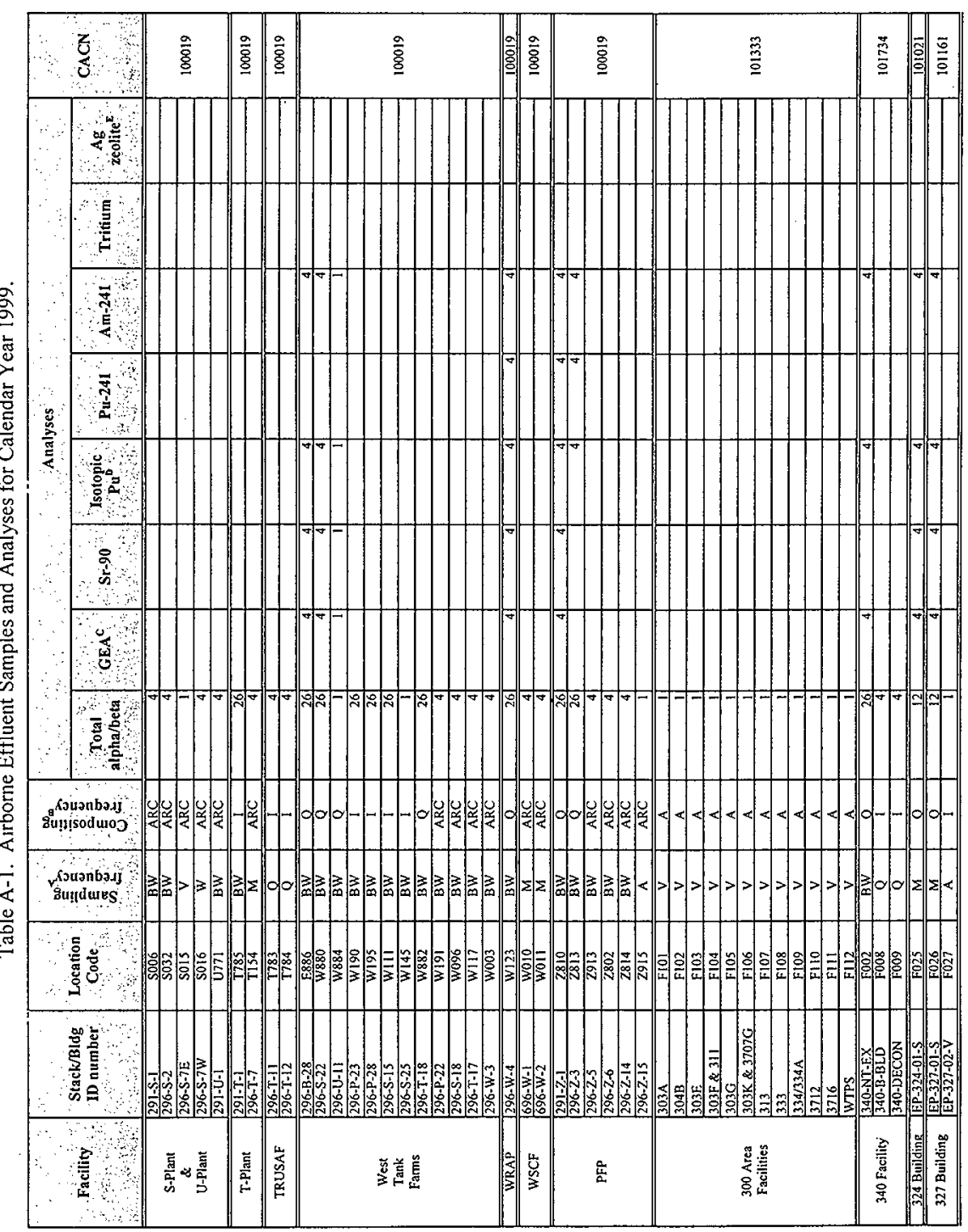


HNF-EP-0835-5

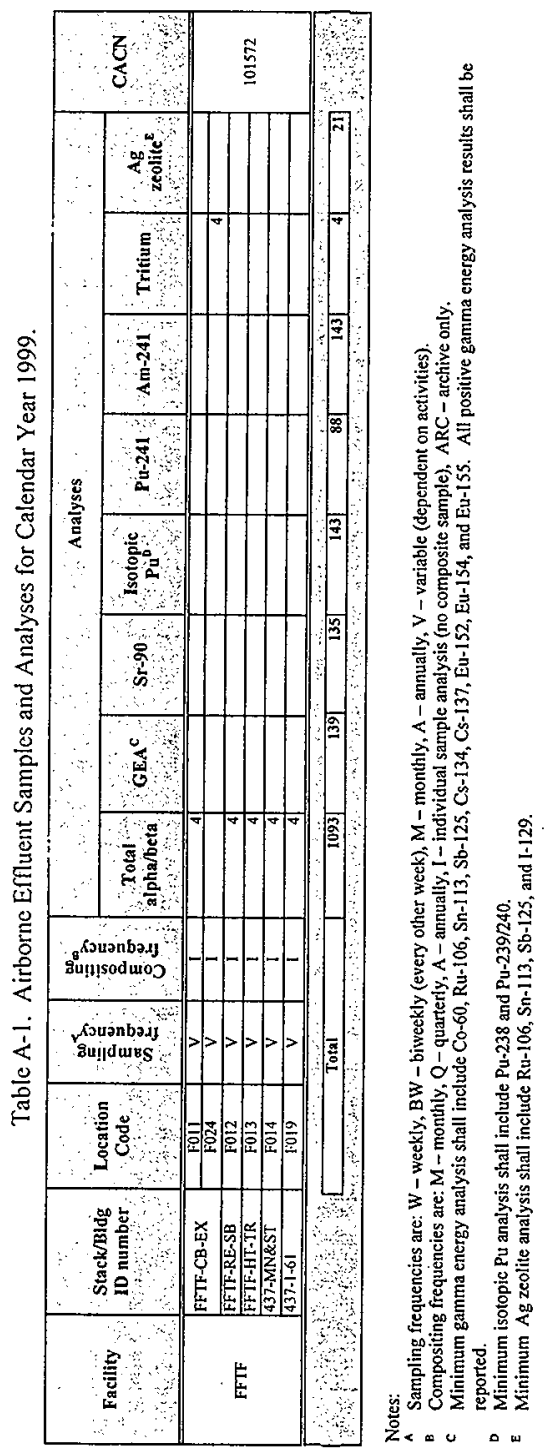


HNF-EP-0835-5

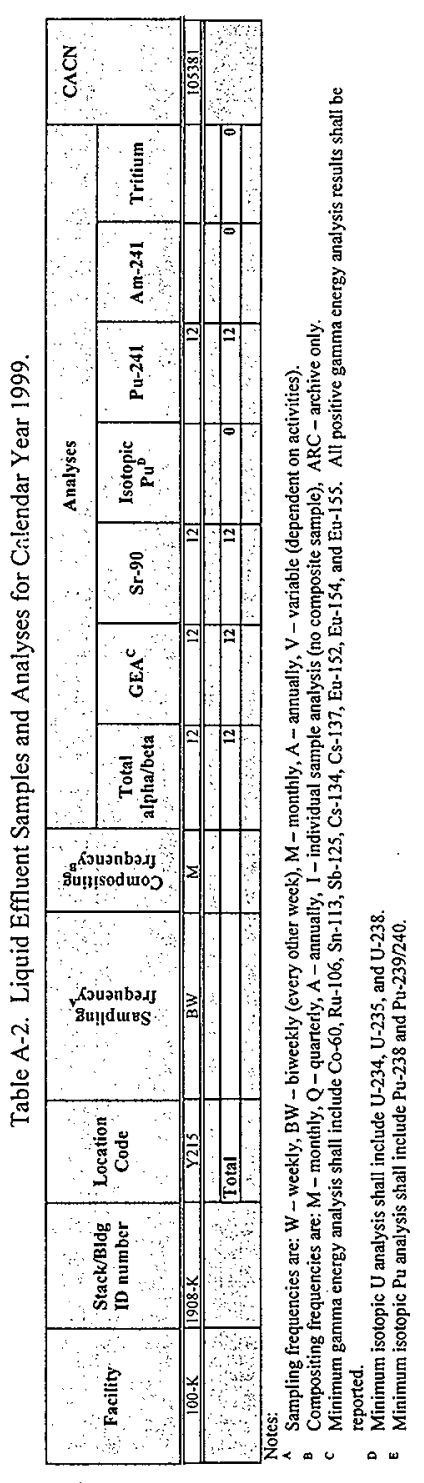


HNF-EP-0835-5

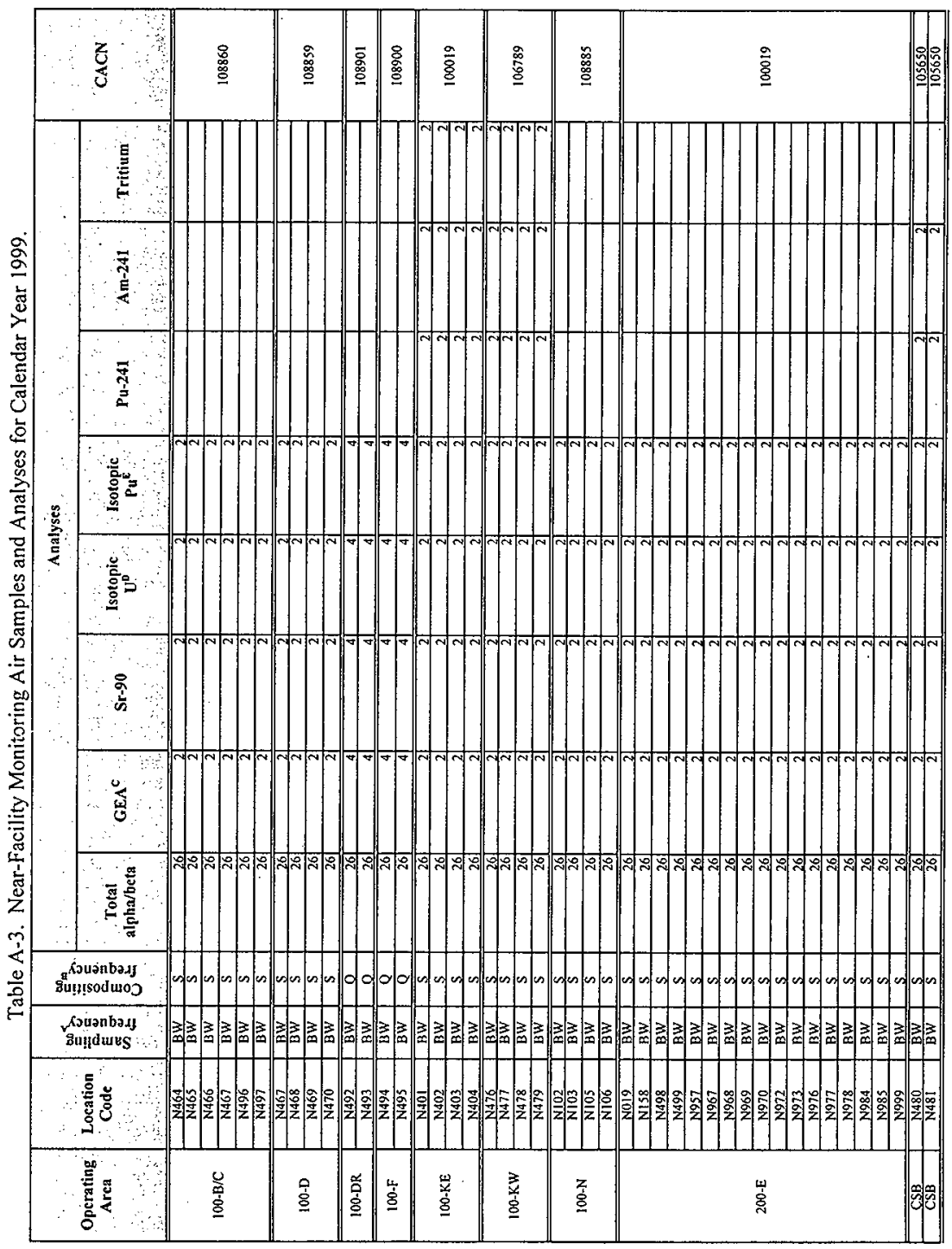


HNF-EP-0835-5

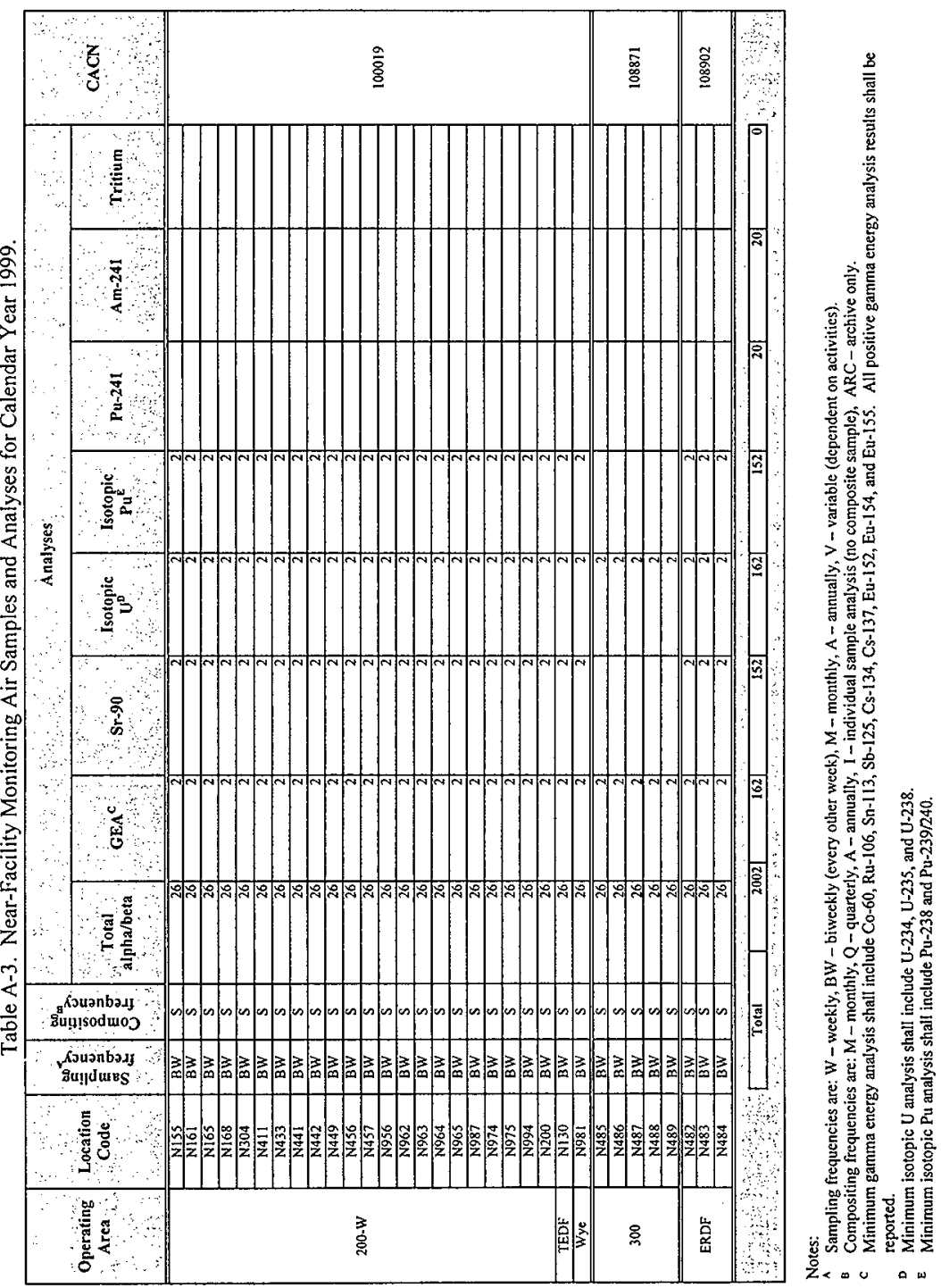




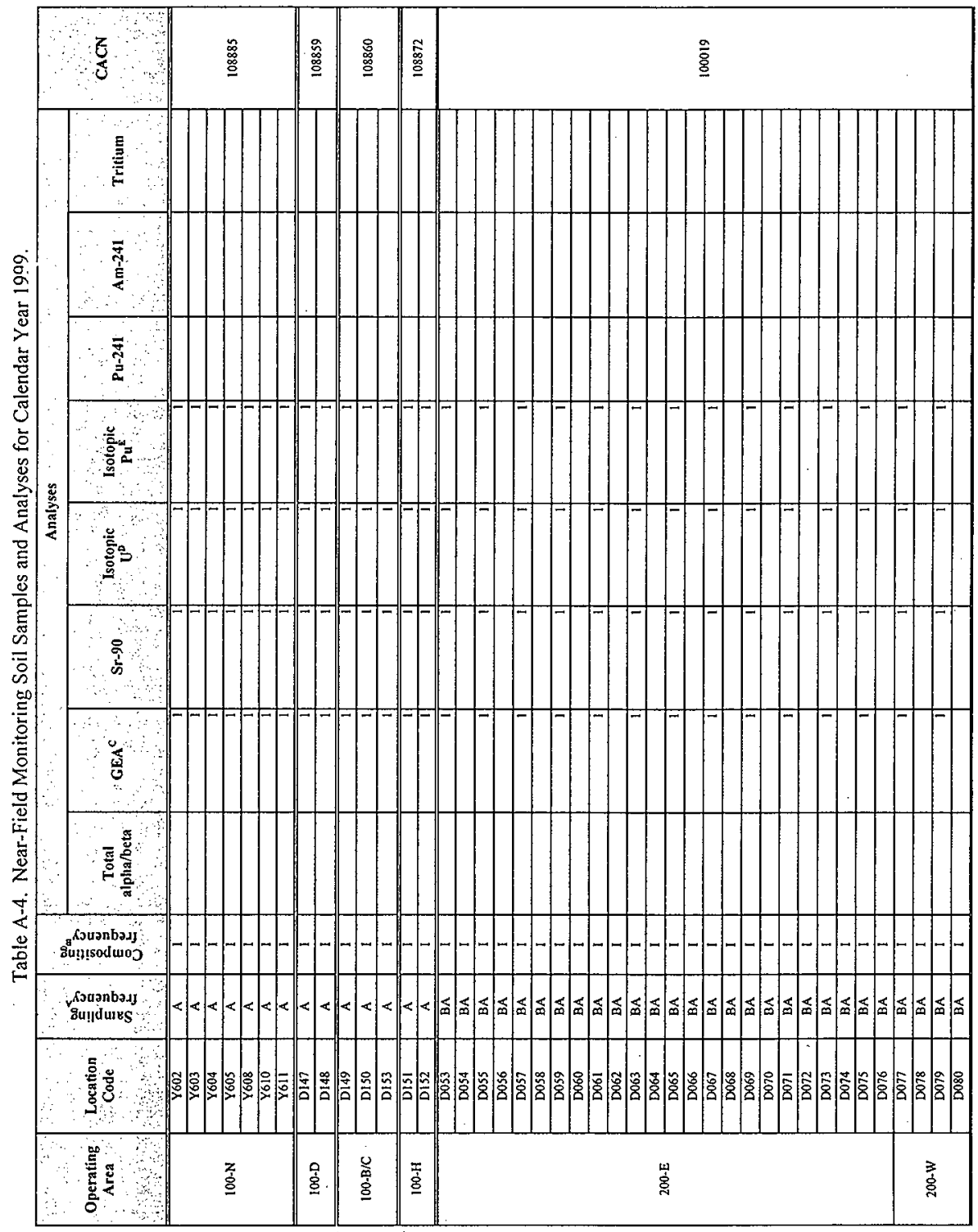


HNF-EP-0835-5

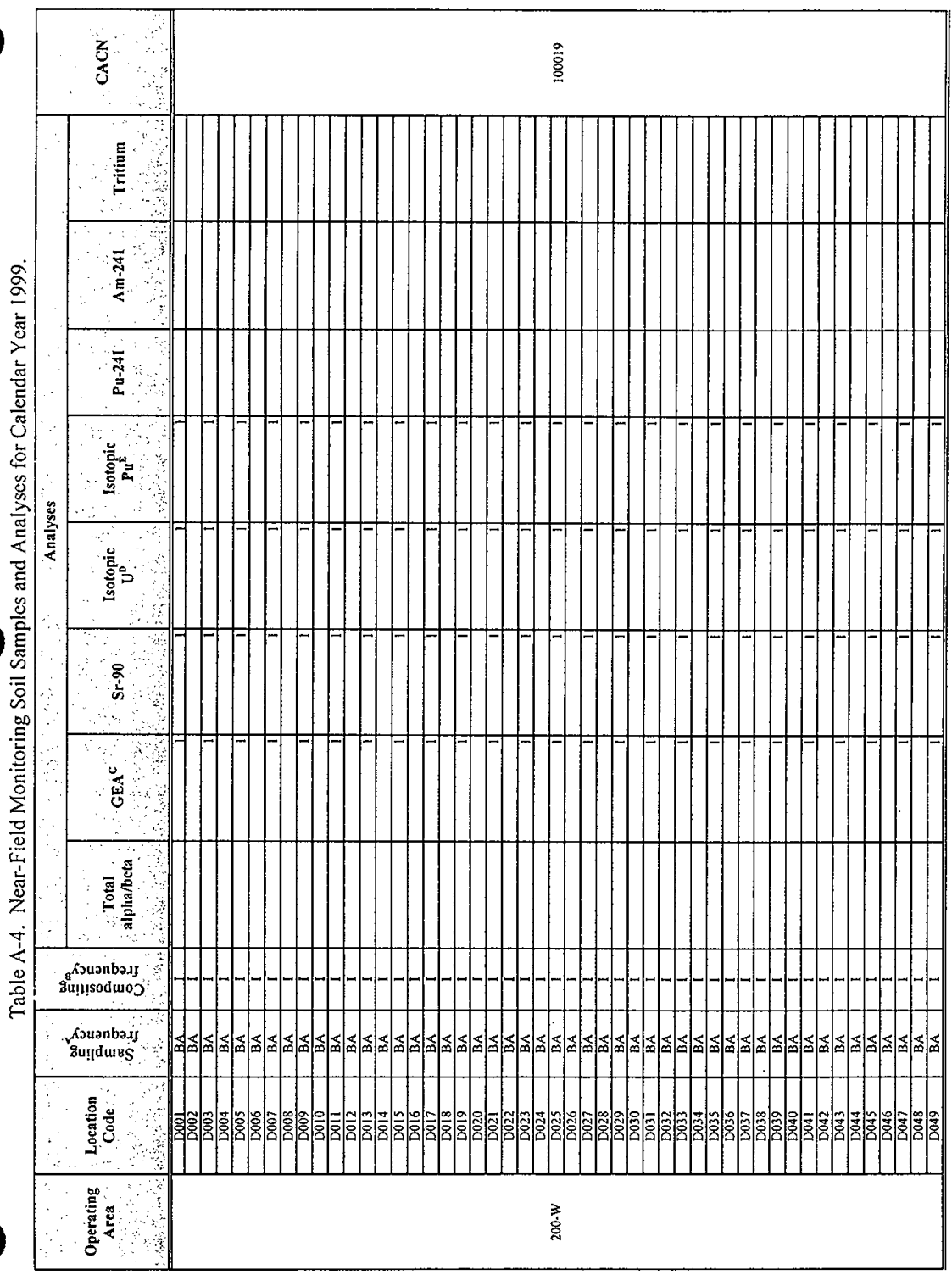



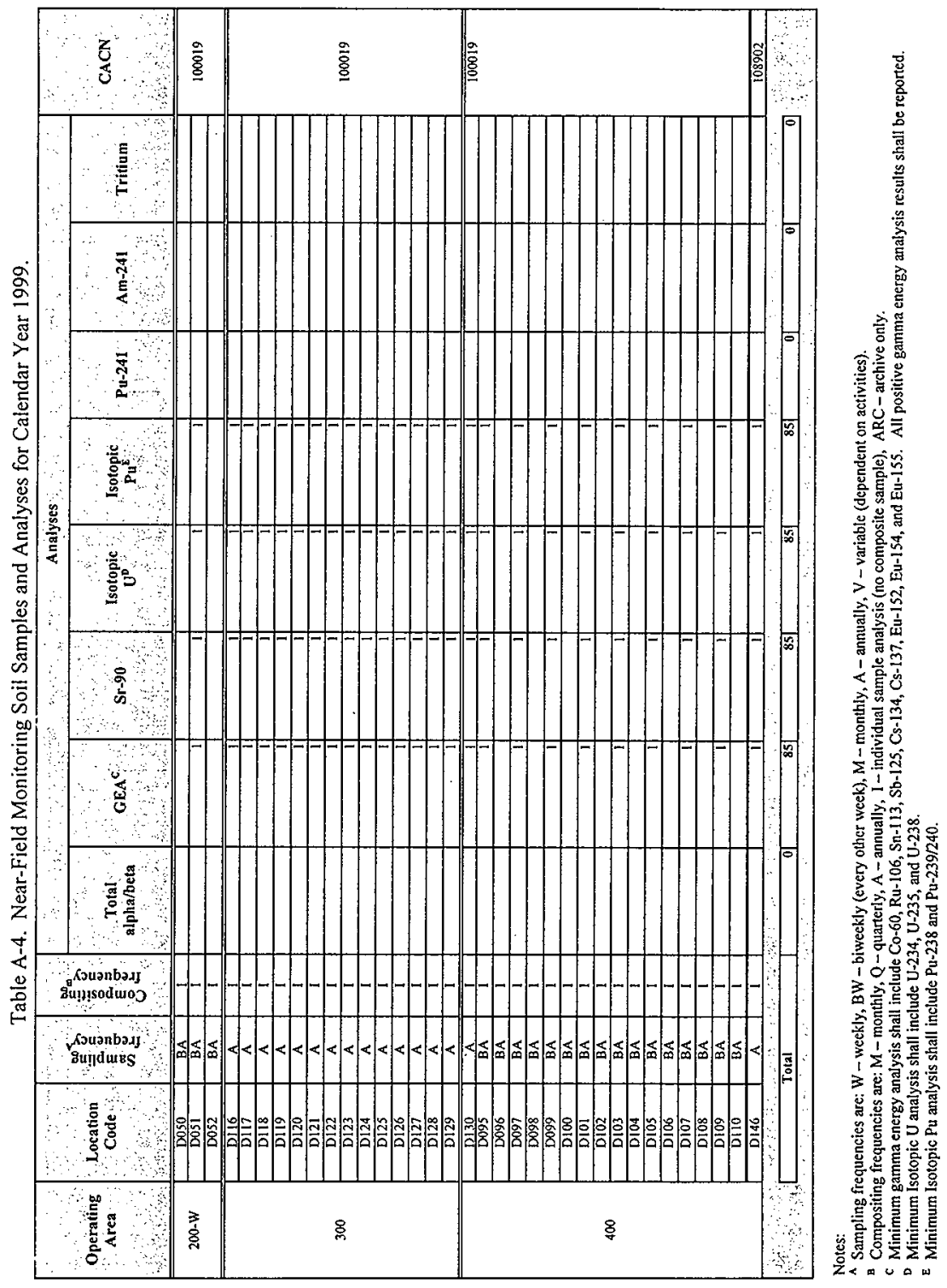


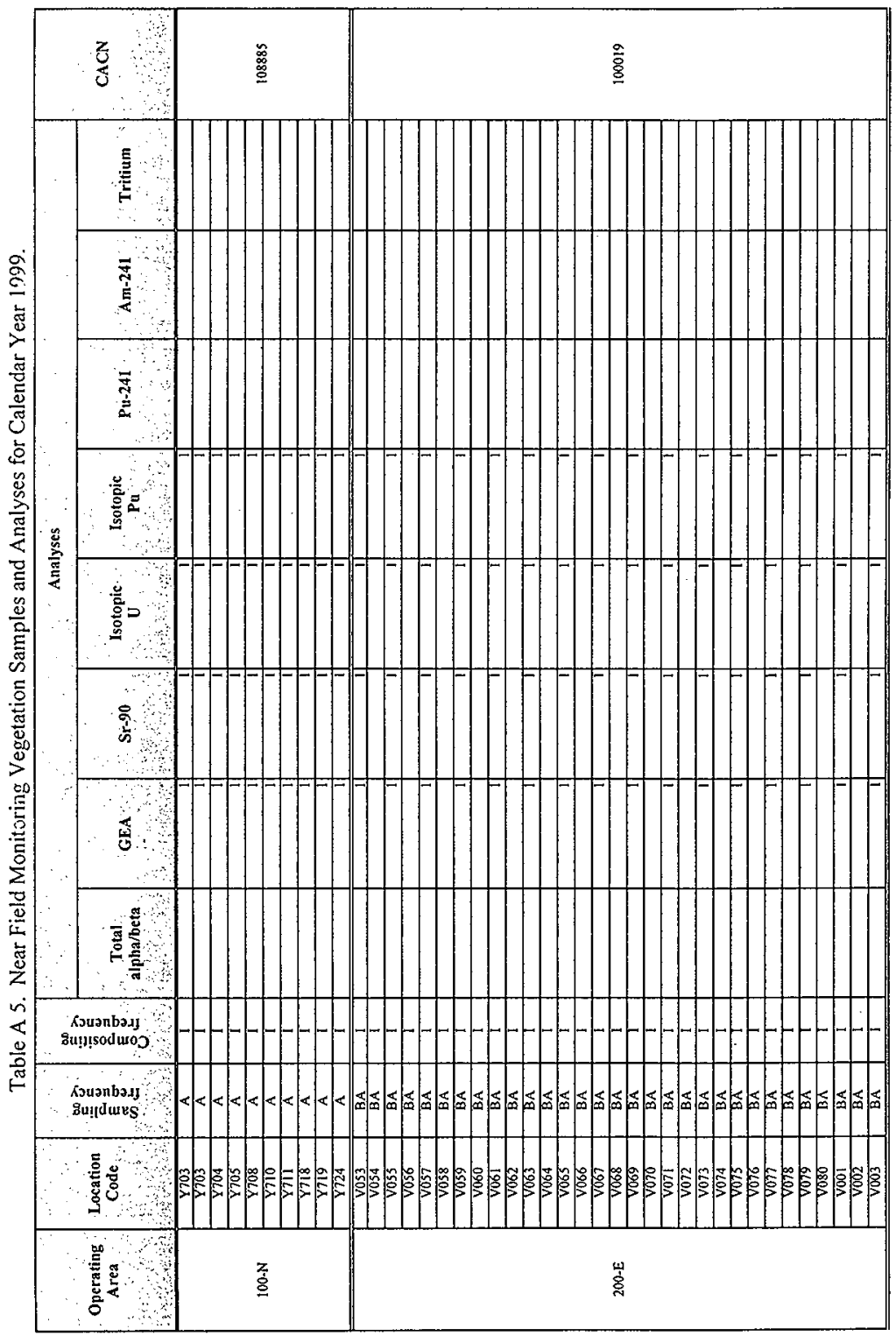


HNF-EP-0835-5

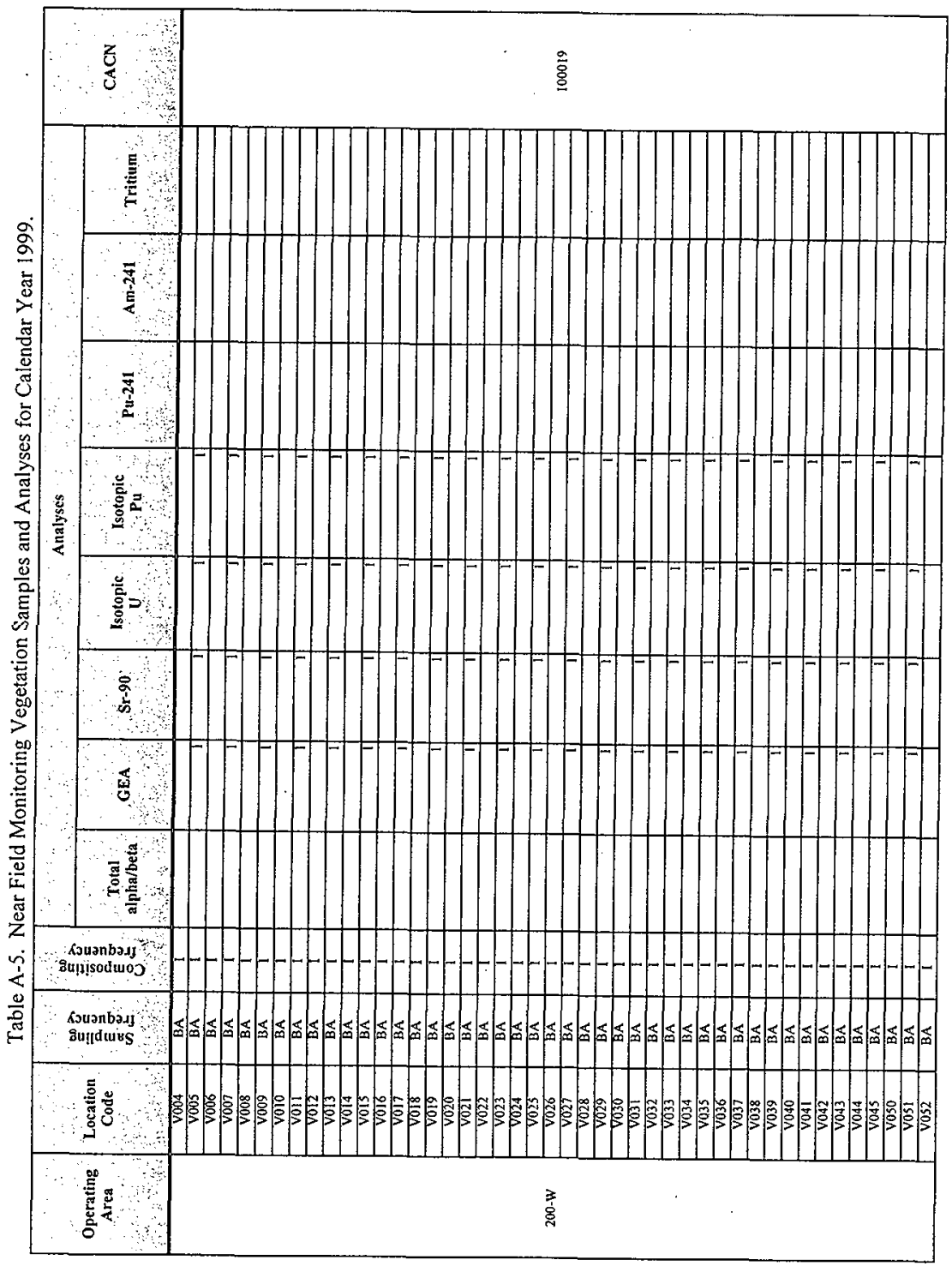




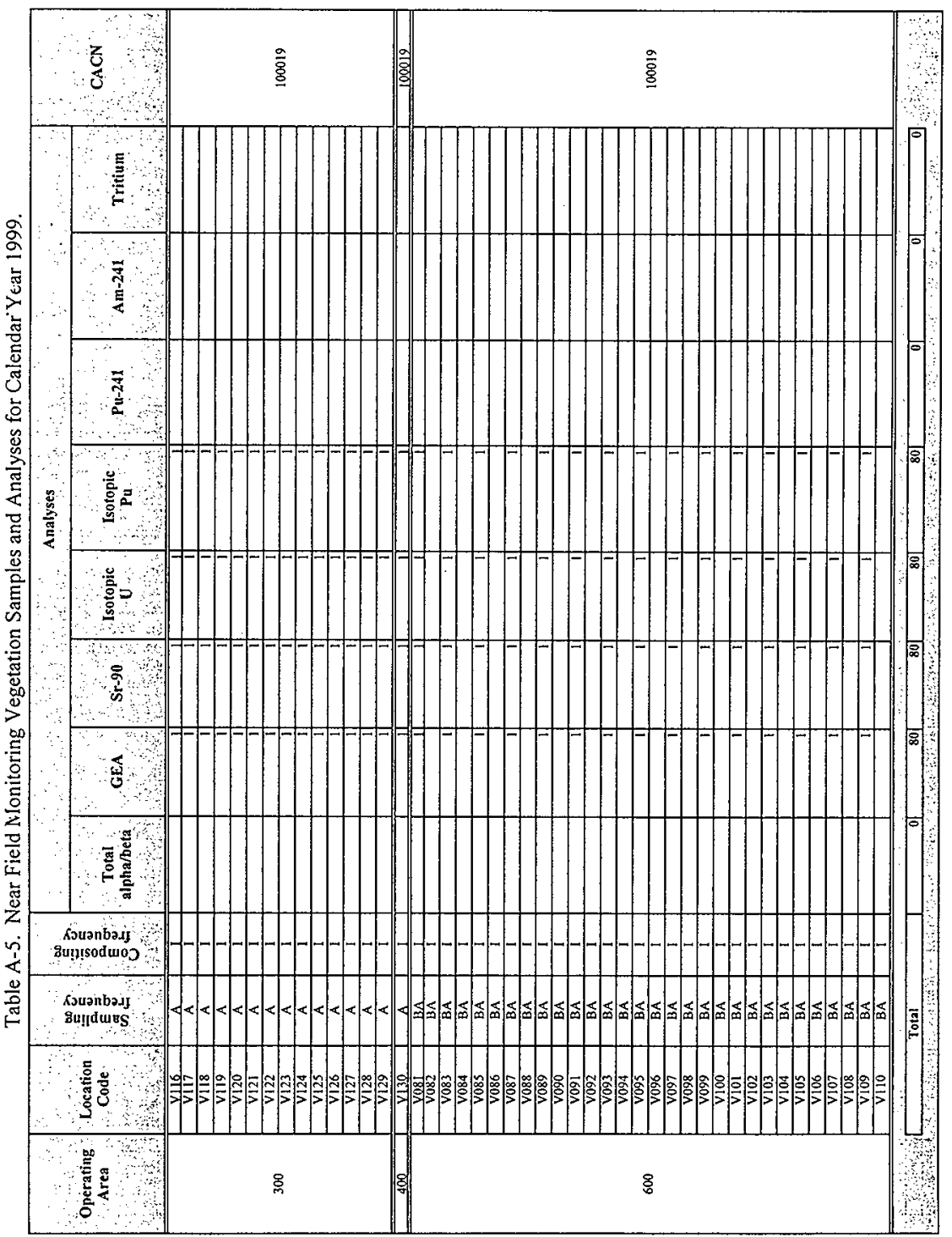


HNF-EP-0835-5

This page intentionally left blank. 
U.S. Department of Energy, Richland Operations Office
A. V. Ingle
A5-15
J. B. Hall
A5-15
D. C. Ward
A5-15
Public Reading Room
$\mathrm{H} 2-53$

Bechtel Hanford, Inc.

R. J. Landon

H0-02

D. W. Long

X5-54

J. E. Rugg

S3-21

J. G. Woolard

$\mathrm{H} 0-02$

J. P. Zoric

$\mathrm{X} 5-53$

Fluor Daniel Hanford, Inc.

K. A. Giese

H6-21

D. G. Ranade

H6-23

S. M. Price

$\times 6-23$

$\underline{B \& W}$ Hanford Company

N. R. Dahl

N2-57

D. L. Johnson

L1-05

D. E. Rasmussen

L1-04

DE\&S Hanford, Inc.

R. G. Gant

X3-79

D. J. Watson

$\times 3-79$

Lockheed Martin Hanford, Inc.

M. J. Brown

Rl-51

G. C. Crummel

R1-51

Lockheed Martin Services, Inc.

J. N. Diven

H8-41

Central Files

B1-07

DPC

H6-08

Pacific Northwest National Laboratory

Hanford Technical Library

P8-55 


\section{DISTRIBUTION (cont)}

S. N. Bakhtiar

S3-28

S. L. Cobb

S3-28

B. M. Colley

S3-28

A. K. Dasgupta (5)

S3-31

L. K. Deere

H6-36

L. P. Diediker (20)

S. L. Fitzgerald

E. M. Greager

T6-50

L. D. Kamberg

H6-36

K. L. Kunzweiler

H6-25

R. E. Johnson

S3-28

H. K. Meznarich

H6-25

K. L. Powell

S3-31

W. R. Thackaberry

S3-30

T4-52

Waste Management Federal Services, Inc.. Northwest Operations

J. J. Dorian

H1-13

A. R. Johnson

H1-13

B. M. Markes

H1-13

S. M. McKinney

H1-12

C. J. Perkins

H1-12 